\title{
HELMINTHS INFECTING Mabuya dorsivittata (LACERTILIA, SCINCIDAE) FROM A HIGH-ALTITUDE HABITAT IN ITATIAIA NATIONAL PARK, RIO DE JANEIRO STATE, SOUTHEASTERN BRAZIL
}

\author{
ROCHA, C. F. D., ${ }^{1}$ VRCIBRADIC, D., ${ }^{1,2}$ VICENTE, J. J. ${ }^{3}$ and CUNHA-BARROS, M. ${ }^{1}$ \\ ${ }^{1}$ Setor de Ecologia, DBAV, I. Biologia, Universidade do Estado do Rio de Janeiro, R. São Francisco Xavier, 524, \\ CEP 20550-013, Rio de Janeiro, RJ, Brazil \\ ${ }^{2}$ Pós-graduação em Ecologia, Departamento de Zoologia, IB, Universidade Estadual de Campinas, C.P. 6109, \\ CEP 13081-970, Campinas, SP, Brazil \\ ${ }^{3}$ Departamento de Helmintologia, Instituto Oswaldo Cruz, CEP 21045-900, Rio de Janeiro, RJ, Brazil \\ Correspondence to: Carlos Frederico D. Rocha, Setor de Ecologia, DBAV, I. Biologia, Universidade do \\ Estado do Rio de Janeiro, R. São Francisco Xavier, 524, CEP 20550-013, Rio de Janeiro, RJ, Brazil, \\ e-mail: cfdrocha@uerj.br \\ Received February 13, 2002 - Accepted August 29, 2002 - Distributed February 28, 2003
}

\begin{abstract}
We analysed the helminth fauna associated with the lizard Mabuya dorsivittata (Scincidae) from a high-altitude area in Itatiaia National Park, Rio de Janeiro State, Brazil. Of the 16 lizards examined, $12(75 \%)$ were infected by at least one helminth. Only two helminth species were found: Physaloptera retusa and Skrjabinodon spinosulus (Nematoda), the former with a prevalence of $68.8 \%$ and a mean infection intensity of $3.6 \pm 2.8$ and the latter with a prevalence of $56.3 \%$ and a mean infection intensity of $2.6 \pm 2.6$. The helminth fauna of the studied population of Mabuya dorsivittata was considerably poorer than those of other previously studied populations of congeners.
\end{abstract}

Key words: Reptilia, lizard, Scincidae, Mabuya dorsivittata, Itatiaia National Park, Atlantic Rainforest.

\section{RESUMO}

\section{Helmintos infectando Mabuya dorsivittata (Lacertilia, Scincidae) em uma área de altitude no Parque Nacional do Itatiaia, Rio de Janeiro, Brasil}

Analisamos a fauna de helmintos associada ao lagarto Mabuya dorsivittata (Scincidae) de uma área de altitude no Parque Nacional do Itatiaia, Rio de Janeiro, Brasil. Dos 16 lagartos examinados, 12 (75\%) estavam infectados por pelo menos um helminto. Apenas duas espécies de helminto foram encontradas: Physaloptera retusa e Skrjabinodon spinosulus (Nematoda), tendo a primeira prevalência de $68,8 \%$ e intensidade média de infecção de 3,6 $\pm 2,8$ e a segunda prevalência de $56,3 \%$ e intensidade média de infecção de 2,6 $\pm 2,6$. A fauna de helmintos da população de Mabuya dorsivittata estudada foi consideravelmente pobre em comparação com as de outras populações congenéricas previamente estudadas.

Palavras-chave: Reptilia, lagarto, Scincidae, Mabuya dorsivittata, Parque Nacional do Itatiaia, Mata Atlântica.

\section{INTRODUCTION}

The Neotropical Mabuya Fitzinger, 1826, constitute a unique monophyletic radiation of that widespread genus, which is characterized by morphological characteristics such as an advanced placental structure and a high and variable number of presacral vertebrae (Blackburn \& Vitt, 1992; Bauer, 1993; Greer et al., 2000). Although some information on endoparasites associated with South American Mabuya species exists in the literature (e.g., Vicente et al., 1993; Van Sluys et al., 1997; Ribas et al., 1998; Vrcibradic et al., 1999, 2000, $2001,2002 a, b)$, there is as yet no data on the 
helminth fauna associated with the relatively widespread (see Cei, 1993) species M. dorsivittata Cope, 1862. Also, most of the above works deal with helminth faunas of Mabuya populations from Brazilian coastal sand-dune habitats ("restingas"; see Eiten, 1992), with the exception of the work of Vrcibradic et al. (1999) on a population of $M$. frenata inhabiting an altered environment within a Cerrado-Atlantic forest transitional area. The purpose of this study is to present data on the helminths of $M$. dorsivittata from a high altitude population in southeastern Brazil. We also compare the helminth fauna of this host population to those of other congeneric populations for which there is available data.

\section{MATERIALS AND METHODS}

Lizards $(\mathrm{n}=16)$ were collected in February 2000 in the Prateleiras region (22 $23^{\prime} \mathrm{S}$; $44^{\circ} 40^{\prime} \mathrm{W}$; altitude $2460 \mathrm{~m}$ ) of Itatiaia National Park, Rio de Janeiro State, Brazil. The Prateleiras Peak, at over $2600 \mathrm{~m}$, is the second highest point of that park, which is situated within the Mantiqueira mountain range. Area vegetation consists of montane scrubby and grassy fields, known as "campos de altitude" (Eiten, 1992; Scarano et al., 2001), with numerous large boulders scattered among the tall grass. While basking on the boulders, lizards were collected with rubber bands and glue-traps placed on the boulder tops. The animals were euthanized with ether, fixed in $10 \%$ formaline and stored in $70 \%$ alcohol.

Subsequently, they were dissected in the laboratory and their digestive tracts and body cavities were examined under a stereomicroscope to check for endoparasite presence. All helminths found were cleared in phenol and mounted on slides for identification under a microscope. Voucher specimens of helminths were deposited at the helminthological collection of the Instituto Oswaldo Cruz (CHIOC 34679-81). We follow Bush et al. (1997) in the use of eco-parasitological terms throughout the text. In addition, descriptive statistics are always given as the arithmetic mean \pm one standard deviation. For each nematode species, the number of individuals (i.e., infection intensity) was correlated with lizard snout-vent length (SVL) using simple regression analyses.

\section{RESULTS}

Two helminth species were recovered from the lizards: the nematodes Physaloptera retusa Rudolphi, 1819 (Spirurida; Physalopteridae) and Skrjabinodon spinosulus Vicente, Vrcibradic, Rocha \& Pinto, 2002 (Oxyurida; Pharyngodonidae). Physaloptera retusa is a widespread species and has been recorded in many New World lizard and snake species (e.g., Baker, 1987; Vicente et al., 1993; Roca, 1997; Vrcibradic et al., 2000). Mabuya dorsivittata represents a new host record for $P$. retusa. Skrjabinodon spinosulus was recently described in the present population of $M$. dorsivittata (Vicente et al., 2002) and is only the second species of the genus recorded from South America (see Vicente et al., 2000). Of the 16 lizards examined, 12 (75\%) were infected by nematodes. Of the twelve infected lizards, eight (66.7\%) harbored both nematode species. The four uninfected ones had a snout-vent length (SVL) range of from 40.0-46.3 $\mathrm{mm}$ and were all immature (judging by the state of their gonads). Infected lizards ranged from 58.8 to $74.3 \mathrm{~mm}$ in SVL $($ mean $=64.9 \pm 3.5 \mathrm{~mm})$ and were all sexually mature. Physaloptera retusa always occurred in the stomach (two lizards also had worms in the esophagus) and had a prevalence of $68.8 \%$ (11/16) and a mean infection intensity of $3.6 \pm 2.8$ (range 1-10). Skrjabinodon spinosulus was found in the small and large intestines (especially the former) and had a prevalence of $56.3 \%(9 / 16)$ and a mean infection intensity of $2.6 \pm 2.6$ (range 1-9). Infection intensities were not correlated with host SVL for either $P$. retusa $\left(\mathrm{r}^{2}=0.04 ; \mathrm{p}=0.54 ; \mathrm{n}=11\right)$ or $S$. spinosulus $\left(\mathrm{r}^{2}=0.002 ; \mathrm{p}=0.91 ; \mathrm{n}=9\right)$.

\section{DISCUSSION}

The helminth fauna of the studied population of $M$. dorsivittata was poor, especially when compared to other Brazilian congeneric populations (Table 1). Nevertheless, it should be pointed out that in some cases (Vrcibradic et al., 1999, 2002a, b) helminth richness values include parasites found in only one host individual, representing accidental occurrences. Thus, a larger sample of $M$. dorsivittata could result in an increase in helminth richness, by augmenting the chance of sampling 
rare or accidental helminths. However, richer helminth assemblages have been reported from Mabuya populations represented by samples smaller than ours (Vrcibradic et al., 2000, 2001, $2002 b)$. It is possible that the low richness of the helminth community of the Itatiaia population of M. dorsivittata may be a result of the relative isolation (insularity effect) of the study area, as observed in other studies (e.g., Dobson et al., 1992; Van Sluys et al., 1997). The "campos de altitude" can be considered "habitat islands" relative to the surrounding wet Atlantic rainforest environment. Nevertheless, despite the poorness of the helminth fauna, both nematode species occurred with high prevalences and can be considered as "core" species (see Dobson \& Pacala, 1992; Bush et al., 1997) for the studied M. dorsivittata population. Mabuya dorsivittata occurs with relatively high density at the study area, a fact that may be partially responsible for the high prevalences of infection observed (see Aho, 1990).

We cannot say if the low species richness and high infection rates observed in the present study are typical of the host species or if they are due to characteristics of the study area, since no available data on parasite assemblages exist for other M. dorsivittata populations. Also, most data in Table 1 refer to populations from a single type of habitat (restinga). More studies on other populations of $M$. dorsivittata and Mabuya species/ populations from different habitats throughout Brazil are needed to obtain a better idea of the parameters of helminth communities in those skinks and to assess the relative importances of host phylogeny and habitat type on these parameters.

Acknowledgments - This study is a portion of the results of the "Programa de Ecologia, Conservação e Manejo de Ecossistemas do Sudeste Brasileiro" and of the Southeastern Brazilian Vertebrate Ecology Project (Laboratory of Vertebrate Ecology), both of the Setor de Ecologia, Instituto de Biologia, Universidade do Estado do Rio de Janeiro. The study was partially supported by research grants from the Fundação de Amparo à Pesquisa do Estado do Rio de Janeiro - FAPERJ (process E-26/170.385/97 - APQ1) and by fellowships from the Conselho Nacional de Desenvolvimento Científico e Tecnológico - CNPq to CFDR (processes n. 300819/94-3 and n. 461970/00 - 7) and to DV (process n. 143607/98-7). We thank C. E. Zikan and L. Nascimento for allowing us to work in the Itatiaia National Park. We also thank M. A. Botelho for guidance in the study area and for field assistance. A permit to collect the lizards was supplied by the Instituto Brasileiro do Meio Ambiente e Recursos Naturais Renováveis - IBAMA (Process n. 098/99).

TABLE 1

Richness of nematode and helminth assemblages for different populations of Mabuya spp. in Brazil. Non-nematode helminths include pentastomids (Raillietiella sp.), acanthocephalans, the cestode Oochoristica ameivae, and the trematode Paradistomum parvissimum. State codes are: $\mathbf{R J}=$ Rio de Janeiro; ES = Espírito Santo; SP = São Paulo; BA = Bahia.

\begin{tabular}{|l|l|c|c|l|}
\hline \multicolumn{1}{|c|}{ Host species } & \multicolumn{1}{|c|}{ Locality } & $\begin{array}{c}\text { Nematode } \\
\text { richness }\end{array}$ & $\begin{array}{c}\text { Total helminth } \\
\text { richness }\end{array}$ & \multicolumn{1}{c|}{ Source } \\
\hline M. agilis & Linhares, ES & 2 & 4 & Van Sluys et al., 1997; unpubl. data \\
\hline M. agilis & Barra de Maricá, RJ & 6 & 7 & Ribas et al., 1998; unpubl. data \\
\hline M. agilis & Carapebus, RJ & 3 & 4 & Vrcibradic et al., 2000; unpubl. data \\
\hline M. agilis & Grumari, RJ & 4 & 7 & Vrcibradic et al., 2002a \\
\hline$M$. agilis & Praia das Neves, ES & 4 & 8 & Vrcibradic et al., 2002b \\
\hline$M$. agilis & Grussaí, RJ & 5 & 9 & Vrcibradic et al., 2002b \\
\hline$M$. dorsivittata & Itatiaia, RJ & 2 & 2 & This study \\
\hline$M$. frenata & Valinhos, SP & 4 & 5 & Vrcibradic et al., 1999 \\
\hline$M$. macrorhyncha & Barra de Maricá, RJ & 3 & 6 & Ribas et al., 1998; unpubl. data \\
\hline$M$. macrorhyncha & Carapebus, RJ & 3 & 6 & Vrcibradic et al., 2000; unpubl. data \\
\hline$M$. macrorhyncha & Trancoso, BA & 3 & 7 & Vrcibradic et al., 2001 \\
\hline$M$. macrorhyncha & Praia das Neves, ES & 4 & 8 & Vrcibradic et al., 2002b \\
\hline$M$. macrorhyncha & Grussaí, RJ & 4 & 7 & Vrcibradic et al., 2002b \\
\hline
\end{tabular}




\section{REFERENCES}

AHO, J. M., 1990, Helminth communities of amphibians and reptiles: comparative approaches to understanding patterns and processes, pp. 157-195. In: G. W. Esch, A. O. Bush \& J. M. Aho (eds.), Parasite communities. patterns and processes. Chapman \& Hall, New York.

BAKER, M. R., 1987, Synopsis of the Nematoda parasitic in amphibians and reptiles. Occ. Pap. Biol., Mem. Univ. Newfoundland, 11: 1-325.

BAUER, A. M., 1993, African-South American relationships, a perspective from the Reptilia, pp. 244-288. In: P. Goldblatt (ed.), Biotic relationships between Africa and South America. Harvard University Press, Cambridge.

BLACKBURN, D. G. \& VITT, L. J., 1992, Reproduction in viviparous South American lizards of the genus Mabuya, pp. 150-164. In: W. C. Hamlett (ed.), Reproductive biology of South American vertebrates. Springer-Verlag, New York.

BUSH, A. O., LAFFERTY, K. D., LOTZ, J. M. \& SHOSTAK, A. W., 1997, Parasitology meets ecology in its own terms: Margolis et al. revisited. J. Parasitol., 83: 575-583.

CEI, J. M., 1993, Reptiles del Noroeste, Nordeste y Este de la Argentina. Herpetofauna de las selvas subtropicales, puna y pampas. Museo Regionale di Scienze Naturali, Torino, 949p.

EITEN, G., 1992, Natural Brazilian vegetation types and their causes. An. Acad. Bras. Ciênc., 64(Suppl. 1): 35-65.

DOBSON, A. P. \& PACALA, S. V., 1992, The parasites of Anolis lizards in the northern Lesser Antilles. II. The structure of the parasite community. Oecologia, 91: 118125 .

DOBSON, A. P., PACALA, S. V., ROUGHGARDEN, J. D., CARPER, E. R. \& HARRIS, E. A., 1992, The parasites of Anolis lizards in the northern Lesser Antilles. I. Patterns of distribution and abundance. Oecologia, 91: 110-117.

GREER, A. E., ARNOLD, C. \& ARNOLD, E. N., 2000, The systematic significance of the number of presacral vertebrae in the lizard scincid genus Mabuya. Amphib.Reptilia, 21: 121-126.

RIBAS, S. C., TEIXEIRA-FILHO, P. F., ROCHA, C. F. D. \& VICENTE, J. J., 1998, Parasitismo por nematóideos em duas espécies simpátricas de Mabuya (Lacertilia: Scincidae) na restinga da Barra de Maricá, RJ. An. Sem. Reg. Ecol., São Carlos, 8(2): 883-894.

ROCA, V., 1997, Natural history notes. Tropidurus melanopleurus. Parasites. Herp. Rev., 28: 204.

SCARANO, F. R., DUARTE, H. M., RIBEIRO, K. T. RODRIGUES, P. J. F. P., BARCELLOS, E. M. B., FRANCO, A. C., BRULFERT, J., DELÉENS, E. \& LÜTTGE, U., 2001, Four sites with contrasting environmental stress in southeastern Brazil: relations of species, life form diversity, and geographic distribution to ecophysiological parameters. Bot. J. Linn. Soc., 136: 345-364.
VAN SLUYS, M., ROCHA, C. F. D., BERGALLO, H. G., VRCIBRADIC, D. \& RIBAS, S. C., 1997, Nematode infection in three sympatric lizards in an isolated fragment of restinga habitat in southeastern Brazil. Amphib.-Reptilia, 18: 442-446.

VICENTE, J. J., RODRIGUES, H. O., GOMES, D. C. \& PINTO, R. M., 1993, Nematóides do Brasil. Parte III: Nematóides de Répteis. Revta. Bras. Zool., 10: 19-168.

VICENTE, J. J., VRCIBRADIC, D., MUNIZ-PEREIRA, L. C. \& PINTO, R. M., 2000, Skrjabinodon heliocostai $\mathrm{sp.}$ n. (Nematoda, Pharyngodonidae) parasitizing Mabuya frenata (Cope) (Lacertilia, Scincidae) in Brazil and the reallocation of Skrjabinodon capacyupanquii (Freitas, Vicente \& Ibañez) in the genus Thelandros. Revta. Bras. Zool., 17: 361-367.

VICENTE, J. J., VRCIBRADIC, D., ROCHA, C. F. D. \& PINTO, R. M., 2002, Description of Skrjabinodon spinosulus $\mathrm{sp} . \mathrm{n}$. (Nematoda, Oxyuroidea, Pharyngodonidae) from the Brazilian lizard Mabuya dorsivittata Cope, 1862 (Scincidae). Revta. Bras. Zool., 19: 157-162.

VRCIBRADIC, D., ROCHA, C. F. D., RIBAS, S. C. \& VICENTE, J. J., 1999, Nematodes infecting the skink Mabuya frenata in Valinhos, São Paulo State, southeastern Brazil. Amphib.-Reptilia, 20: 333-339.

VRCIBRADIC, D., CUNHA-BARROS, M., VICENTE, J. J., GALDINO, C. A. B., HATANO, F. H., VAN SLUYS, M. \& ROCHA, C. F. D., 2000, Nematode infection patterns in four sympatric lizards from a restinga habitat (Jurubatiba) in Rio de Janeiro State, southeastern Brazil. Amphib.-Reptilia, 21: 307-316.

VRCIBRADIC, D., ROCHA, C. F. D., VAN SLUYS, M. \& BURSEY, C. R., 2001, Natural history notes. Mabuya macrorhyncha. Endoparasites. Herp. Rev., 32: 256-257.

VRCIBRADIC, D., ROCHA, C. F. D., BURSEY, C. R. \& VICENTE, J. J., 2002a, Helminths infecting Mabuya agilis in a "restinga" habitat (Grumari) of Rio de Janeiro, Brazil. Amphib.-Reptilia, 22: 109-114.

VRCIBRADIC, D., ROCHA, C. F. D., BURSEY, C. R. \& VICENTE, J. J., 2002b, Helminths communities of two sympatric skinks (Mabuya agilis and Mabuya macrorhyncha) from two "restinga" habitats in southeastern Brazil. J. Helminthol., 76: in press. 